\title{
Aspects of 'Parody' And 'Play within a Play' in Shakespeare's Twelfth Night.
}

\author{
Dr. Shirin Sadallah Rasheed ${ }^{1 *}$, Kawa Othman. O. Ahmed ${ }^{2}$ \\ ${ }^{1}$ Lect. Department of English College of Education University of Salahadin \\ ${ }^{2}$ Department of Translation College of Languages University of Sulaimani
}

*Corresponding Authors: Dr. Shirin Sadallah Rasheed, Lect. Department of English College of Education University of Salahadin

\begin{abstract}
The research investigates aspects of parody and 'play within a play' in Shakespeare's Twelfth Night (1601-1602). One important issue to be investigated is the parodic relation between two interrelated plots in this romantic comedy. The main focus is on the play's subplot with regard to the aspects of 'parody' and 'play within a play'. The play's minor-plot, as the research demonstrates, parodically reflects on the play's main themes and dramatic action. There is also a striking similarity and parodic relation between the two female protagonists in both interrelated plots with regard to female protagonists' witty usage of language and deceptive schemes. Such parodic relationship reaffirms the play's essential message in respect to female protagonists' quest for individuality and selfhood. This is in accord with Shakespeare's humanist and feminist perspective with regard to woman's right in determining her own destiny. The current research is significant for many reasons, Above all, it shed lights on unexplored aspects in Shakespeare's romantic comedy such as the dramatic technique of parody and 'play within a play'.
\end{abstract}

Keywords: Parody, Sub-Plot, Verbal Skill, Role-Playing, Individuality.

\section{INTRODUCTION}

The insertion of a sub-plot within the major plot is a common dramatic motif in Shakespearean romantic comedy. Shakespeare's Twelfth Night (1601-1602), for instance, contains multiple plots and diverse dramatic incidents. Noticeably, the play's minor plot functions as a 'play within a play'. Such plot contains many metatheartical aspects such as play within a play, asides and role playing. These methatheatrical features have important dramatic functions. Whereas the major plot deals with "serious and intense romantic love inherited from the medieval courtly tradition, the sub-plot is entirely comic and even farcical in tone." (Ray, 2007, P.157). Both plots, however, share similar themes such as mistaken identity, self-deception, disguise and courtship. They even share similar dramatic structure. "It is convenient to discuss the play in terms of main plot and subplot, romance and comedy; and the characters of the comic subplot do constitute a distinct society within the play." (Carneage \& Houlahan, 2014, P.1 7). Romantic Moreover, the romantic plot in the play mainly deals with the development of a love relationship between two main protagonists, whereas the sub-plot deals with a comic scheme set by a group of low-ranked characters against the main villain. One of the core issues the research tries to investigate is the dramatic significance of the subplot, particularly with regard to female protagonist's quest for selfhood, as well as, the extent the heroine's witty usage of deceptive schemes in the subplot contributes to restoration of order and harmony to the community.

\section{A Brief Overview of Parody and 'Play within a Play' In Elizabethan Drama}

The dramatic feature of 'Metatheatre' or 'Self-Referentiality', is quite common in Shakespearean plays. "A well-known classical example of literary self-reference is the play within the play in Shakespeare's Hamlet". (Nöth \& Bishara, 2007: 208)., Christopher Marlowe had also employed same dramatic technique in his play. Such theatrical technique constitutes an important aspect in Marlowe's tragedy Doctor Faustus (1589 - 1592). In Shakespeare's Hamlet, the metatheatrical subplot functions as satirical parody of the main plot. In this play, "Hamlet enlists actors to perform a play duplicating aspects of his father's murder); parody that mocks theatrical conventions; and 
reference to the performance's actors." (Buzzard. \&Don. 2014: 92). In Marlowe's Doctor Faustus, similarly, the sub-plot functions as a satirical parody of the major action and themes in the main plot. The minor plot in Marlowe's tragedy centers around the "adventures" of Robin, a clown, who seems to be a mocking imitation of Faustus's adventures. Here, the dramatic function of the subplot "as parody seems clear". (Kendrick, 2004: 227-228). The theatrical device of "play within a play' is also a common feature in Shakespearean romantic comedies. In Shakespeare's Twelfth Night (1601-1602), for instance, there is a parodic relation between the major plot and subplot. The play's sub-plot offers a scene which can be termed a 'play within a play'. Such theatrical device is expressed through a minor form of drama, or 'minor play' within the original play. In this 'minor play', a group of players ply a deceptive trick on the play's main villain. The deceptive trick is planned by Maria, a witty and quite intelligent female protagonist in the sub-plot, to expose the villain's false manners and attitudes.

\section{Maria's Tricky Scheme as a Parody of Viola's Deceptive Role-Playing}

Maria's playful deceptive scheme in the sub-plot against Malvolio, the play's main villain, signals a shift from romance to comedy. Such dramatic shift is marked by a change in the linguistic style from "verse to prose". Comic characters in Shakespeare's comedies mostly talk in " prose" .(Caenegie, \& Houlahan, 2014 : 17 ), unlike essential characters who mostly deliver speeches in verse. The major plot deals with two developing love stories among young lovers, whereas the subplot deals with a less serious issue. The seriousness of the love stories among the conflicting young lovers in the major plot, moreover, is contrasted against the trivial and comic situation of the comic characters in the minor plot. "Shakespeare has created a group of downstairs roisterers whose antics parallel, mimic, or mingle with those of the upstairs aristocracy." (Shurgot,\& Owens, 1998: 144 ). The sub-plot, significantly, serves multiple dramatic functions. Above all, it theatrically reflects on the contrasts between falsehoods versus truth, appearance versus. Reality, and self-delusion versus self-realization. Malvolio's false manners and his delusion about the prospect of marrying Olivia, the Lady of the household, is a satiric parody of Orsino's delusive affection for Lady Olivia, or even Olivia's selfdelusion about Cesario, who is in fact a woman in disguise. In other words, Malvolio's delusive affection for Lady Olivia can be considered as the satirical equivalent of Orsino's 'love-sickness', as well as, Lady Olivia's own delusion about Viola/ Cesario. These false and deceptive love situations in the play are contrasted against Viola's sincere love for Orsino and Sebastian's growing affection for Olivia, or even the growing romance between Sir Toby and Maria. Noticeably, a parallel can be drawn between the two female protagonists in both plots. Viola and Maria, as two main heroic figures in the main-and-subplots, share personality traits and characteristics. Both heroines are intelligent and skilful in using witty speeches, and they both employ deception and trickeries for the sake of revealing truth from falsehood

The sub-plot presents a group of minor characters whose roles are merely meant to to provide comic relief. Unlike Orsino and Olivia in the main plot, Both Sir Toby Belch and Sir Andrew Aguecheek represent two comic figures in the subplot. "Sir Toby Belch and Sir Andrew, though they belong to the aristocracy, cannot be taken seriously for, Sir Toby does not have a serious attitude and Sir Andrew is a fool" (Ray , 2007: 157 ). Other marginal figures in the sub-plot such as, Maria, Malvolio, Feste and Fabian, don't belong to aristocracy and "are not nobly born". (Ray, 2007: 157). Sir Andrew Aguecheek and Sir Toby Belch share similar personality traits. They are typical prototypes of comic figures common in the Elizabethan comedies. They "can be seen as a classic comic pairing: fat and thin, witty and foolish, joker and straight man."(Caenegie, \& Houlahan, 2014: 17). Malvolio, on the other hand, represents a typical embodiment of "comic villain" in the play. His arrogant attitudes and rigid assertion of authority in Olivia's household is in clear contrast with Maria's tolerant and fun-loving personality. "He fantasizes himself as contentedly wed to Oliver for three months. He intends to use his power as the Countess's husband to command staff members and to demoralize Sir Toby for merry-making". (Snodgrass, 2008: 5). Contrary to Malvolio, Maria is morally and intellectually superior to other comic characters. Her wit and cunning rhetoric ultimately enables her to rise above her modest social class. Similar to Viola in the main plot, Maria plays two different roles; one as a servant, and another as a trickster. "It is Maria's literacy skills, however, that ultimately characterize her as a witty and resourceful servant worthy of reward via marriage". (Dowd, 2009: 40). Notably, Maria's role-playing in the subplot proves to be as much effective as Viola's disguise in the main plot. 
In Olivia's household, Maria is given liberty to express her opinions openly without being punished. She frequently speaks "on behalf of Olivia, who has declared that she will not admit any suitors for seven years since she is mourning her dead brother". (Novy, 2017: 132). Maria's strong rhetoric is proven during her witty dialogues either with Malvolio, or with both Sir Toby and Sir Andrew. Through witty speeches, Maria could deliver her covert critiques against characters' wrongdoings. Sir Toby Belch finds Maria's witty speeches amusing. He admires her quick wit and cunning speeches. She nonetheless expresses discontent about both characters' ill-mannered attitudes. Her criticism, however, is mostly directed against Sir Andrew's foolish attitude in Lady Olivia's household. There is nonetheless a hidden affection between Maria and Sir Toby Belch. The following speech, for instance, provides hints about Maria's leading role in Countess's household:

\section{MARIA}

Ay, but you must confine yourself

within the modest limits of order.

\section{SIR TOBY BELCH}

Confine? I'll confine myself no finer than I am.

These clothes are good enough to drink in,

and so be these boots too. An they be no

let them hang themselves in their own straps. (1.3. 7-12).

Similar to Viola's role-playing in the main plot, Maria could easily shift social roles. Role-playing and disguise, from a feminist perspective, can be viewed as effective strategies against patriarchy as they provide means for the victimized women to alter and transform their personas as well as their social classes. By implication, Maria's deceptive scheme against Malvolio can be considered as equivalent parody of viola's multiple disguises in the major plot. To cure Orsino from excessive 'lovesickness', Viola has disguised herself as a male page by the name of Cesario. Furthermore, Viola's disguise enables Olivia to leave her unrealistic delusion about love. At the final Act, both Orsino and Olivia acknowledge their past mistakes and ultimately reconcile their differences. Similarly, Maria's high moral standards and her witty character make her quite unique among the surrounding characters. She relentlessly instructs others to behave in proper manners in Countess Olivia's household. She blames Sir Toby for bringing Sir Andrew Aguecheek 'a foolish knight', to be Lady Olivia's 'wooer'. Sir Andrew, contrary to Maria, is illiterate and shallow character whose sole interest lies in merry-making and drinking. He foolishly fancies that he has all the potentialities and means to marry Lady: 'I would I had bestowed that time in the tongues / that I have in fencing, dancing, and bear-baiting. / O, had I but followed the arts!' (1. 3. 27-9). This comic character, ironically, can be considered as an equivalent parody of Malvolio's self-delusion about Lady Olivia. Maria constantly criticizes Sir Andrew Aguecheek's ignorance and ill-mannered personality. This is apparent in the following speech in which Maria sarcastically mocks Sir Andrew's shallow manners:

\section{MARIA}

Ay, but you must confine yourself

within the modest limits of order.

\section{SIR TOBY BELCH}

Confine? I'll confine myself no finer than I am.

These clothes are good enough to drink in,

and so be these boots too. An they be no

let them hang themselves in their own straps. (1.3. 7-12).

Similar to Viola's role-playing in the main plot, Maria could easily shift social roles. Role-playing and disguise, from a feminist perspective, can be viewed as effective strategies against patriarchy as they provide means for the victimized women to alter and transform their personas as well as their social classes. By implication, Maria's deceptive scheme against Malvolio can be considered as equivalent 
parody of viola's multiple disguises in the major plot. To cure Orsino from excessive 'lovesickness', Viola has disguised herself as a male page by the name of Cesario. Furthermore, Viola's disguise enables Olivia to leave her unrealistic delusion about love. At the final Act, both Orsino and Olivia acknowledge their past mistakes and ultimately reconcile their differences. Similarly, Maria's high moral standards and her witty character make her quite unique among the surrounding characters. She relentlessly instructs others to behave in proper manners in Countess Olivia's household. She blames Sir Toby for bringing Sir Andrew Aguecheek 'a foolish knight', to be Lady Olivia's 'wooer'. Sir Andrew, contrary to Maria, is illiterate and shallow character whose sole interest lies in merry-making and drinking. He foolishly fancies that he has all the potentialities and means to marry Lady: 'I would I had bestowed that time in the tongues / that I have in fencing, dancing, and bear-baiting. / O, had I but followed the arts!' (1. 3. 27-9). This comic character, ironically, can be considered as an equivalent parody of Malvolio's self-delusion about Lady Olivia. Maria constantly criticizes Sir Andrew Aguecheek's ignorance and ill-mannered personality. This is apparent in the following speech in which Maria sarcastically mocks Sir Andrew's shallow manners:

\section{SIR ANDREW}

Good Mistress Accost, I desire better acquaintance

MARIA

My name is Mary, sir.

\section{SIR ANDREW}

Good Mistress Mary Accost. (1.3. 50-53).

Sir Andrew in the above speech confuses the term 'accost' for Maria's name. It clearly displays his ignorance and lack of knowledge about the prescribed norms and codes of courtship. Similar to Malvolio, Sir Andrew is a self-deluded character whose prospect of marriying Olivia ends tragicaly. They both represent satirical parody of ill-mannered courtiers. Sir Toby witingly exploits Sir Andrew's igniorance and amuses himself by tricking the courtier into believing that he is a perfect choice of his niece Lady Olivia. He had taken 'some two thousand strong, or so' (3.2. 52-53) from him. The most amusing moment occurs in in the final Act when Sir Toby tricks Sir Andrew into challenging Cesario/Viola. Sir Toby's wit and playful manners make him a perfect match of Maria. He praises Maria's witty character as as 'Penthesilea' and 'a beagle true bred' Thier union in a happy marriage constitutes a significant part of multiple weddings at the end of the romantic comedy.

\section{Aspect OF 'A Play Within a Play' in the Minor-Plot}

The conflict in the play's subplot arises because of power struggle between Malvolio and Maria in Olivia's household. Olivia's steward is a power seeker, and he tries desperately to overtake Lady Olivia's household, while Maria courageously resists the steward's lust for power. The following lines, for instance, underlines Malvolio's authoritative role in Lady Olivia's household:

\section{MALVOLIO}

Mistress Mary, if you prized my lady's favor

at anything more than

contempt, you would not give

means for this uncivil rule.

She shall know of it, by this hand. (2 . 3 .118-121).

Maria finds Malvolio's shallow manners and his pretence of authority in Olivia's household unbearable. She displays a strong-willed character when she decides challenging Malvolio in front of Sir Toby and Sir Andrew: 'If I do not gull him into a nayword and make him a common recreation, Ido not think I have wit enough to lie straight in my bed. I know I can do it. (2 .3. 131-133).' Maria plans her revenge by tricking Malvolio into believing that he is favourite match for Olivia. Her staged deceptive scheme, which can be viewed as 'a play within a play', aims to bring Malvolio to disclose his malicious scheme to overtake Olivia's household. Both Sir Toby and Sir Andrew joyfully join Maria's deceptive scheme against the Olivia's Steward. This is evident in the following exchange in 
which Maria and two other courtiers mockingly criticize Malvolio's reserved and seemingly 'puritanical' manners:

\section{MARIA}

The devil a puritan that he is, or anything constantly, but a time-pleaser; an affectioned ass that cons state without book and utters it by great swarths; the best persuaded of himself, so crammed, as he thinks, with excellencies, that it is his grounds of faith that all that look on him love him. And on that vice in him will my revenge find notable cause to work. $(2.3,142-1248)$.

Molvolio's Puritanism, as described mockingly by Maria and others, has invoked different interpretations from critics. Probably, the dramatist had presented such comical figure to satirically allude to certain norms and manners by the Puritans during the Elizabethan era. In this respect, the comical depiction of Malvolio's excessive pretence of virtue on stage is meant to make "the Puritan(s) detestable and ridiculous". (Walsh, 2016: 97). Moreover, Maria's reference to Malvolio's 'Puritanism' may also allude to the theme of 'excess' in the play. A Similarity can be drawn between Malvolio's hypocrisy, particularly his excessive pretence of piety and virtue in the sub-plot, and Orsino's excessive display of sentimentality in the main plot. Parallel to Viola's attempt to temper Orsino's excessive passion, Maria in the minor plot undertakes the task of tempering the excess in Malvolio's rigid manners. Significantly, the theme of excess versus confinement recurs in most of Shakespeare's romantic comedies. In As you like it (1601-1602), for instance, Rosalind plays essential role in changing Orlando's personality. "Through linguistic grappling, Rosalind hopes not to kill Orlando's love for her but to temper its excess. (Hunt, 2008: 21). Shakespeare's Twelfth Night, similarly, addresses the theme of excess versus 'confinement'. Maria's trick in the play is set to disclose Malvolio's evil intention, namely his excessive desire to take charge of Olivia's household. The deceptive scene, ironically, provides a parody of the main plot in which Viola, disguised as Cesario, tricks Orsino to reveal his 'excessive' desire for Olivia. Ironically, the relationship between Maria and Malvolio does not end up so much romantic as it is the case with Viola and Orsino. In the main plot, Viola, disguised as Cesario, is "attending and ultimately curing her beloved's lovesickness" (Schiffer, 2011: 8). Contrary to Viola, Maria executes her deceptive scheme in order to punish, or even reform Malvolio's personality. The scene in which Maria tricks Malvolio contains many metatheatrical elements such as, asides, role-playing, disguise, mimicry, and 'play-within-theplay':

the play within the play is often used as a form of irony and can be disguised as a simple performance within the play itself, a character masquerading as another character, a character pretending to be out of his mind, or a complex fusion of theatrical realities". (Fischer, And Greiner 2007:15).

Maria's act of individuality begins when she takes upon herself the task of restoring order and harmony to Olivia's household. As a proof of her strong-willed character, Maria impersonates Olivia's character by forging her handwriting. Her impersonification of Lady Olivia's personality, implicitly, alludes to viola's impersonating of a male character in Orsino's court. To execute the staged trick, Maria writes an anonymous love letter" and leaves it "on the garden path for Malvolio to find". (Snodgrass, 2008: 4). She then asks Sir Toby, Fabian, and Sir Anrew to hide themselves and monitor Malvolio's trivial manners once he discovers the anonymous love letter. In the letter, Malvolio was instructed to wear "yellow hose and tie his garters around his knees" (Snodgrass, P.5, 2008: 5). The purpose of the witty trick, as described by Maria and other conspirators, was to expose the steward's hypocrisy, as well as, "his egotistical posturing." (Snodgrass, 2008: 4). After finding the letter, Malvolio discloses his evil intention to overtake Olivia's household. In a soliloquy, he refers to a real-life incident in which a steward married his Lady:

\section{MALVOLIO}

There is example for't.

The lady of the Strachy

married the yeoman of the wardrobe (2. 5.36-37).

Malvolio, as the above speech demonstrates, is deluded about the prospect of marrying Lady Olivia. Apparently, "he misunderstands the structure of the English peerage, wrongly anticipating that 
marriage to a countess would make him a count.” (Garber, 2004: 529). Maria's trickery, as she has planned, would force Malvolio to express his evil scheme to overtake Olivia's household. Through a staged deceptive scene, Maria has instructed a group of conspirators such as Feste, Sir Toby and Sir Tony Belch to hide themselves and witness how Malvolio behaves as he appears in front of Olivia; 'dressed in yellow hose and tied his garters around his knees' ( 2 . 5.115-223). The deluded steward performs what the letter had instructed him to do so. He smiles when he sets his eyes on Olivia, and acts as the letter required him to do so. He recites the lines written in the anonymous letter: 'some are born great, some achieve greatness, and some have greatness thrust upon them'. (2. 5. 141-143.). The scene in which he reads the letter on stage through a monologue is one of the most comic moments in the play:

\section{MALVOLIO}

'Tis but fortune, all is fortune. Maria once told me she did affect me, and I have heard herself come thus near, that, should she fancy, it should be one of my complexion. Besides, she uses me with a more exalted respect than anyone else that follows her. What should I think on't? ( 2. 5. 21-26.).

The humorous scene provides some comic relief in the play. Such humorous scene nonetheless, can be viewed as a 'play within a play', as a group of plotters conspire among themselves to trick Malvolio. This is quite evident through a sequence of humorous speech exchanges among the plotters:

\section{SIR ANDREW}

(aside) Fie on him, Jezebel!

\section{FABIAN}

(aside) O, peace! Now he's deeply in.

Look how imagination blows him.

\section{MALVOLIO}

Having been three months married

to her, sitting in my state

\section{SIR TOBY BELCH}

(aside) $\mathrm{O}$, for a stone-bow, to hit him

in the eye!

\section{MALVOLIO}

Calling my officers about me, in my

branched velvet gown, having come

from a daybed, where I have left

Olivia sleeping-

SIR TOBY BELCH

45(aside) Fire and brimstone!

FABIAN

(aside) O, peace, peace! (2.5.38-48.).

Noticeably, the first trick on Malvolio contained many ironic asides and humorous exchanges, either between Sir Belch and Fabian, or between Sir Toby and Maria. Such humorous scenes reflect satirically on main themes and motifs in the main plot such as mistaken identity, self-delusion and disguise. Here, Maria's staged trick on Malvolio can be considered as equivalent parody of Viola's deceptive tricks on both Duke Orsino and Lady Olivia.

\section{The Significance of The Second Deceptive Scheme in the Minor-Plot}

The most humorous moment in the play takes place when Malvolio appears in front of Lady Olivia dressed awkwardly, and reciting lines from the anonymous letter by Maria. Lady Olivia has been puzzled by Malvolio's strange outlook and cannot comprehend his strange utterance. She asks Maria 
to care for the confused Steward. Maria cunningly uses this opportunity to further torment the proud and arrogant steward. Her next trick aims to bring Malvolio into confessing his wrongdoings. Sir Toby, Sir Andrew and Feste once again join Maria's next deceptive trick on Malvolio. Sir Toby suggests to Maria "to have Malvolio bound and locked in a dark room." (Bloom, 2008:12-13). Here, the dark room symbolizes Malvolio's self-delusion. The plotters try to justify their actions by alleging "Malvolio is possessed by demons and needs an exorcism".( Minigan, $2006: 20)$. The staged scene in which characters perform exorcism on him is another 'play within a play'. Such staged scene, moreover, parodies another scene in the main plot in which Viola tries to cure Orsino from excessive 'love-sickness'. "After the conspirators have massed suitable 'evidence' for Malvolio's possession, the stage is set for the exorcist to appear" (Kallendorf , 2003: 34). Through a pre-arranged plot, Maria divides roles among her fellow plotters. Feste, disguised as Sir Tubas, or 'the priest', begins interrogating and performing exorcism on Malvolio. Symbolically, Malvolio's forced imprisonment in a dark room provides a satiric parody of Duke Orsino's self- imposed exile from society, or even Olivia's self-imposed isolation for seven years. Similar to previous deceptive scheme, Maria's second deceptive scheme against Malvolio contains many metatheatrical elements such as, asides, roleplaying, mimicry, and the 'play-within-the-play'. This is evident through several exchange of speeches among the conspirators who perform the mocking act of exorcism such as the following lines :

FESTE (as Sir Topas)

(disguising his voice) what ho, I say! Peace in this prison!

\section{SIR TOBY BELCH}

The knave counterfeits well. A good knave.

\section{MALVOLIO}

(from within) who calls there?

FOOL

Sir Topas the curate, who comes to visit Malvolio the lunatic.

\section{MALVOLIO}

Sir Topas, Sir Topas, good Sir Topas, go to my lady

FOOL

Out, hyperbolical fiend! How vexest thou this man! Talkest thou nothing but of ladies?

\section{SIR TOBY BELCH}

(aside) Well said, Master Parson. (4.2.18-24).

During the act of exorcism, the plotters press Malvolio to acknowledge his previous mistakes and confess his sins. Feste, disguised as Sir Tobas, presses Malvolio to confess his sins otherwise he would be kept locked inside the dark room. The plotters' staged performance is meant to trick Malvolio into confessing his wrongdoings in Lady Olivia's household. Their cunning role-playing, in fact, give impression as if "Malvolio is possessed by demons and needs an exorcism." ( Minigan, 2006: 20). No matter what Malvolio says, the conspirators take Malvolio's words as proofs to condemn him."Ironically, his refusal only corroborates their accusations."( Kallendorf, 2003: 34). To further humiliate Malvolio, Feste and other plotters questioned the steward's state of mind: "But tell me true, are you not mad indeed, or do you but counterfeit? (4.2.114-115), for which the steward replies, 'Believe me, I am not; I tell thee true'. ( 4. 2.116 ) In a mocking tone, Feste orders the imprisoned Malvolio to "leave thy vain bibble-babble'..( 4. 2. 96-97). The speech is satiric in its intent, for it ridicules " Malvolio's supposedly exaggerated behavior and language”. ( Elam, 2008: 308). The scene of exorcism, with its sarcastic and comic nature, provides a satiric parody of Vioal's witty trick to cure both Olivia and Orsino from their state of 'love-sicknesses'. A parallel can be drawn between Malvolio's of delusion and Orsino's self- imposed exile in his court, or even Olivia's selfimposed isolation in excessive grief for a dead brother. After the scene of exorcism, Malvolio's fate is left up to Lady Olivia. The Countess expresses admiration for Maria's witty scheme, while at the same time expresses her deep concern about what happened to 
Malvolio:

OLIVIA

Alas, Malvolio, this is not my writing,

Though, I confess, much like the character.

But out of question, 'tis Maria's hand.

And now I do bethink me, it was she

First told me thou wast mad, (5.1.339-343).

Ironically, the discovery of Maria's deceptive letter happens at a time most dramatic confusions and conflicts in the main plot are getting resolved. Like other typical villains in Elizabethan plays, Malvolio is portrayed as an element of disruption and discord against the play's romantic atmosphere. And his degradation also signals a new beginning in the play as the conflicting young lovers reconcile among themselves. After the trickery scene, Malvolio appears weak and confused. Lady Olivia has taken Maria's trick on Malvolio less seriously and she even expresses admiration for her witty trick. This angers Malvolio and his threatening speech: 'I'll be reveng'd on the whole pack of you' (5.1.378), against the conspirators indicates his discontent at Lady Olivia's indifferent to what happened to him. Contrary to Malvolio's degradation at the end of the play, Viola and Maria gain higher social status through two happy marriages. Duke Orsino is united with Viola after the confusion about the twin brother, Sebastian and Viola, is clarified at the final Act. Maria, too, secures a higher social position in Olivia's household by marrying Sir Toby.

By impersonating Lady Olivia's character, Maria has symbolically challenged society's conventional prejudice and misconceptions about women's gender roles in society. In a way, both Viola's cross-dressing in the main plot and Maria's deceptive role-playing in the subplot constituted two effective subversive strategies for both victimized women against Illyria's patriarchal society. From a feminist perspective, Maria's role-playing in the subplot empowered her since her acting theatrically challenged and debunked false notions and misconceptions about women in Illyria's male-dominated community. Indeed, her cunning role-playing empowered her as much as disguise and cross-dressing empowered Viola in the main plot. The happy romantic ending in the play, through multiple marriages among the conflicting young lovers in both sub-and main-plots, in fact signals the restoration of order and harmony to Illyria's community. Both Orsino and Olivia reconcile their differences after the discovery of the twin sister and brother, Sebastian and Viola. Noticeably, both female protagonists sub-and main plot have contributed to such happy outcome.

\section{CONCLuSion}

The Minor-Plot in Shakespeare's Twelfth Night has a significant dramatic function. Such plot, metatheatricaly, reflected on main themes and dramatic actions of major plot. The dramatist successfully blended both humour and seriousness through two parallel and co-related plots. Whereas the main plot dealt with serious love story, the sub-plot dealt with less serious issue. Both plots, nonetheless, tackled almost similar themes and motifs such as romantic love, courtship, mistaken identity, role-playing and disguise. Maria's staged deceptive scheme in the sub-plot, which can be viewed as 'a play within a play', aimed at revealing the villain's ill-mannered attitude towards women. Her deceptive trick provided a satirical parody of Viola's tricky role-playing in the major plot. A parallel can be drawn between both female protagonists in both plots. Similar to Viola's role-playing in the main plot, Maria could easily shift social roles. Her role-playing in the subplot through a deceptive scheme against the main villain can be considered as equivalent parody of viola's multiple disguises in the major plot. Through deceptive tricks, both female protagonists in two different plots could expose male characters' false notions and misconceptions about women. From a feminist perspective, both disguise and role-playing can be considered as subversive strategies against patriarchy, for they provide effective means for the victimized women to alter and transform their personas as well as their social classes. This is quite evident in the play's final Act when both female protagonists achieve higher social status in Illyria's male-dominated society.

\section{REFERENCES}


[1] Bloom, Harold, and Pamela Loos. (2008). Bloom's Shakespeare through the Ages: Twelfth Night. New York: Bloom's Literary Criticissm.

[2] Buzzard, Laura, and Don Lepan. (2014). The Broadway Pocket Glossary of Literary Terms. Canada: Broadway Press.

[3] Caenegie, David, and Mark Houlahan. Twelfth Night, Or What You Will - ISE - Ed. Carnegie: A Broadview Internet Shakespeare Edition. Canada: Broadview Press .2014.

[4] Dowd, Michelle M. Women's Work in Early Modern English Literature and Culture. Palgrave Macmilian. 2009.

[5] Elam, Keir. The Arden Shakespeare -Twelfth Night: Third Series. UK: Cengage Learning AS .2008.

[6] Fischer, Gerhard. And Bernhard Greiner. edit. The Play within the Play: The Performance of MetaTheatre and Self-Reflection. Amsterdam: Rodopi B.V. 2007.

[7] Gaggi, Silvio. Modern/Postmodern: A Study in Twentieth-Century Arts and Ideas. Philadelphia: University of Pennsylvania Press. 1989.

[8] Garber, Marjorie. Shakespeare after All. US: Anchor Books, A division of Random House, Inc. New York. 2004

[9] Hunt, Maurice. M. Shakespeare's As You Like It: Late Elizabethan Culture and Literary Representation. Palgrave Macmillan. 2008.

[10] Kallendorf , Hilaire. Exorcism and Its Texts: Subjectivity in Early Modern Literature of England and Spain. Canada: University of Toronto Press Incorporated 2003

[11] Kendrick, Christopher. Utopia, Carnival, and Commonwealth in Renaissance England. Canada: University of Toronto Press .2004

[12] Logan, Robert A. Shakespeare's Marlowe: The Influence of Christopher Marlowe on Shakespeare's Artistry.USA: University of Hartford.2007.

[13] Minigan, John. Twelfth Night, Or, What You Will: A Play in One Act. US: Theatrefolk Original playscripts. 2006

[14] Nöth, Winfried and Bishara, Nina. EDIT. Self-Reference in the Media. Deutsch National bibliotihek. 2007.

[15] Novy, Marianne. Shakespeare and Feminist Theory. UK: Bloomsbury Arden Shakespeare, Bloomsbury Publishing Plc. 2017

[16] Ray, Ratri. The Atlantic Critical Studies: William Shakespeare's Twelfth Night. Atlantic Publishers \& Distributors (P) LTD. 2007.

[17] Schiffer, James. Twelfth Night: New Critical Essays. US: Routledge , 2011.

[18] Shurgot, Michael W. \& Owens, Margaret E. Stages of Play: Shakespeare's Theatrical Energies in Elizabethan Performance. Newark and London: University of Delaware Press, Associated University Presses. 1998.

[19] Smith, R. Bruce. Twelfth Night : Texts And Contexts. Macmillan University, 2016.

[20] Snodgrass, Marry. Ellen. Shakespeare on the Double! Twelfth Night. New Jersey : Wiley Publishing, Inc. 2008

[21] Taban, Carla. Meta- and Inter-Images in Contemporary Visual Art and Culture. Belgie: Leuven University Press. 2015

[22] Walsh, Brian. Unsettled Toleration: Religious Difference on the Shakespearean Stage. UK: Oxford University Press.2016.

[23] White, R.S. Avant-Grade Hamlet: Text, Stage, Screen. Fairleigh Dickinson University Press. 2015.

Citation: Dr. Shirin Sadallah Rasheed, Kawa Othman. O. Ahmed. “Aspects of 'Parody' And 'Play within a Play' in Shakespeare's Twelfth Night”. International Journal on Studies in English Language and Literature (IJSELL), vol 8, no. 9, 2020, pp. 13-21. doi: https://doi.org/10.20431/2347-3134.0809002.

Copyright: (c) 2020 Authors. This is an open-access article distributed under the terms of the Creative Commons Attribution License, which permits unrestricted use, distribution, and reproduction in any medium, provided the original author and source are credited. 